\title{
Direct Strength Method for Web Crippling of Cold-formed Steel C- and Z- sections Subjected to One-flange Loading
}

Martin Dara and Cheng Yu*

Department of Engineering Technology, University of North Texas, Denton, TX, USA

\begin{abstract}
Cold-formed steel flexural members can experience buckling failure at the web when compressive loads are applied to the flanges. Determining the web crippling strength analytically can be difficult because it depends on various parameters including loading conditions, bearing length, thickness of the material, web inclination, flange lengths etc. Due to these parameters, the current design method was developed based on the experimental data only. The paper presents an attempt to develop a semi-analytical design approach for the web crippling strength using the Direct Strength Method concept. The focus is on the cold-formed steel C and Z sections subjected to onflange loading conditions. The research indicates that the Direct Strength Method is appropriate for predicting the web crippling strength. New design equations are proposed and verified by with the experimental results.
\end{abstract}

Keywords: Cold-formed steel; Direct strength method; Web crippling; ABAQUS

\section{Introduction}

Web crippling is an important limit state in the structural design of cold-formed steel (CFS) flexural members. Due to the large slenderness ratio, the web element of CFS members tends to cripple at the areas of compression loads or bearing supports. The North American Specification for Cold-Formed Steel Structural Members [1] defines four loading cases for web crippling: End-One-Flange (EOF) loading, Interior One-Flange (IOF) loading, End-Two-Flange (ETF) loading and Interior Two-Flange (ITF) loading as shown in Figure 1. The current AISI S100 [1] design provision for web crippling is based on extensive experimental results by Winter et al. [2] Zetlin [3], Hetrakul et al. [4] Yu [5], Santaputra [6], Santaputra et al. [7], Bhakta et al. [8], Wing [9], Wing et al. [10], Prabakaran [11], Beshara et al. [12] and Young et al. [13]. In the 1996 AISI Specificssation and previous editions, different equations were adopted for web crippling strength. Since the 2001 edition, the AISI Specification began using a unified equation with different coefficients for determining the nominal web crippling strength for different cases. The unified design method was developed by Prabakaran [11], Prabakaran et al. [14] and Beshara [15]. As per AISI S100 [1], the nominal web crippling strength can be calculated as follows.

$$
\mathrm{P}_{\mathrm{n}}=\mathrm{Ct}^{2} \mathrm{~F}_{\mathrm{y}}(\sin \theta)\left(1-\mathrm{C}_{\mathrm{R}} \sqrt{\frac{\mathrm{R}}{\mathrm{t}}}\right)\left(1+\mathrm{C}_{\mathrm{N}} \sqrt{\frac{\mathrm{N}}{\mathrm{t}}}\right)\left(1-\mathrm{C}_{\mathrm{h}} \sqrt{\frac{\mathrm{h}}{\mathrm{t}}}\right)
$$

where $C$ is the web crippling coefficient, $C_{h}$ is the web slenderness coefficient, $C_{N}$ is the bearing length coefficient, $C_{R}$ is the inside bend radius coefficient, $\mathrm{F}_{V}$ is the yield strength of steels, $\mathrm{h}$ is the flat dimension of web measured in plane of web, $\mathrm{N}$ is the bearing length of load, $\mathrm{R}$ is the inside bend radius, $t$ is the web thickness and $\theta$ is the angle between plane of web and plane of bearing surface.

The Direct Strength Method (DSM), originally proposed by Schafer et al. [16], is a new generation design methodology for CFS members. The method has been formally adopted by the North American Specification for the Design of Cold-Formed Steel Structure Membersand the Australian/New Zealand Standard for Cold-Formed Steel Design. Compared with the Effective Width Method, DSM is more reliable and has specific advantage on solving complicated section problems and distortional buckling cases. However DSM is currently capable of determining the nominal strength of members under flexural, compression, and shear forces. It is therefore meaningful to expand DSM to address the web crippling strength. A previous research by Choy et al. [17], explored the application of DSM concept to CFS sections subjected to two flange loading. The research presented in this paper is a continuation of Choy et al.'s work to investigate the DSM on CFS C- and Z- sections subjected to one flange loading conditions. The goal is to prove the concept that DSM works for the limit state of web crippling.

\section{Elastic buckling of $c$ - and $z^{-}$sections subjected to web crippling failures}

The Interior one-flange loading tested data and the End-one-flange loading tested data is taken from researches conducted at different universities $[4,8,13,18]$. With the help of specimen figures, parameters and test setup data the elastic buckling analysis is performed in ABAQUS. The specimens were drafted in ABAQUS and elastic buckling analysis was performed. The value $\mathrm{P}_{c r}$ which is the critical elastic buckling load for the member is taken from ABAQUS.

The ABAQUS models in this research simulated the actual loading and boundary conditions of the tests adopted from the literature. Figure 2 shows an ABAQUS model for $\mathrm{C}$ sections with IOF condition. Figure 3 shows the elastic buckling results from the ABAQUS, the IOF case has buckling occurred under the interior loading. Figure 4 shows a ABAQUS simulation on a $\mathrm{Z}$ section in EOF loading, it can be seen that the buckling occurs at the end support locations.

*Corresponding author: Cheng Yu, Associate Professor, Department of Engineering Technology, University of North Texas, Denton, TX, USA, Tel: $940-$ 891-6891; E-mail: cheng.yu@unt.edu

Received October 13, 2015; Accepted December 10, 2015; Published Decembe 17, 2015

Citation: Dara M, Yu C (2015) Direct Strength Method for Web Crippling of Coldformed Steel C- and Z- sections Subjected to One-flange Loading. J Steel Struct Constr 1: 105. doi:10.4172/jssc. 1000105

Copyright: ( 2015 Dara M, et al. This is an open-access article distributed under the terms of the Creative Commons Attribution License, which permits unrestricted use, distribution, and reproduction in any medium, provided the original author and source are credited. 
Citation: Dara M, Yu C (2015) Direct Strength Method for Web Crippling of Cold-formed Steel C- and Z- sections Subjected to One-flange Loading. J Steel Struct Constr 1: 105. doi:10.4172/jssc.1000105
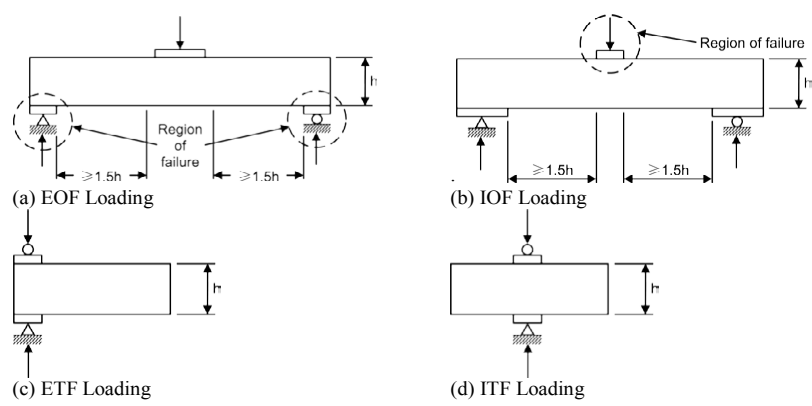

Figure 1: Four loading conditions for web crippling tests.

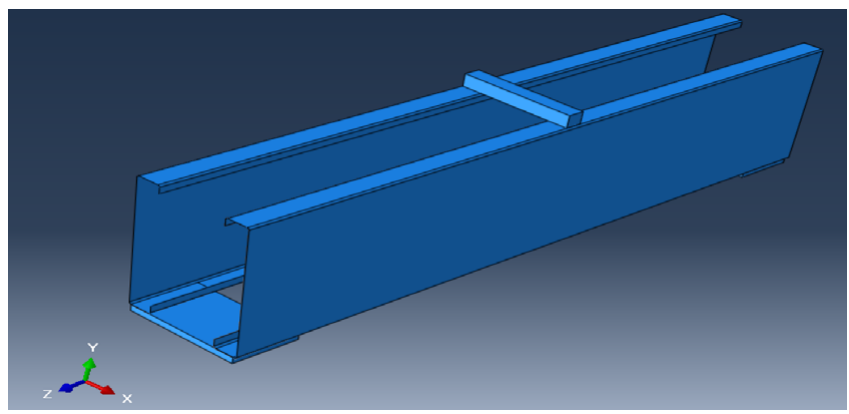

Figure 2: Assembly of C-sections and bearing plates.

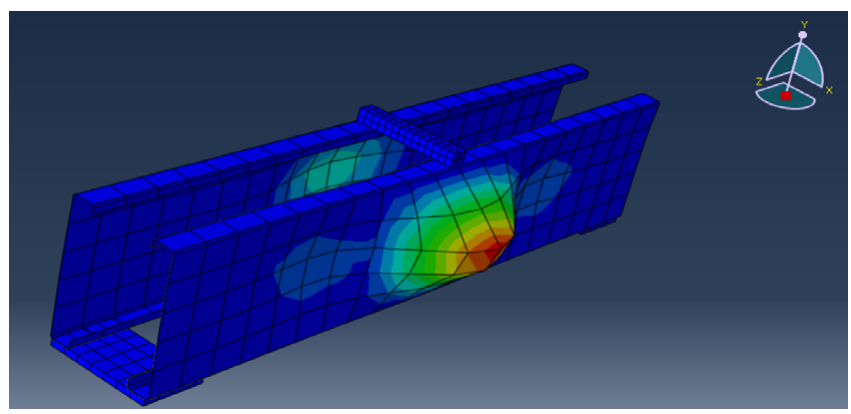

Figure 3: Web crippling of CFS C-section (stiffened flanges) subjected to Interior One-Flange loading.

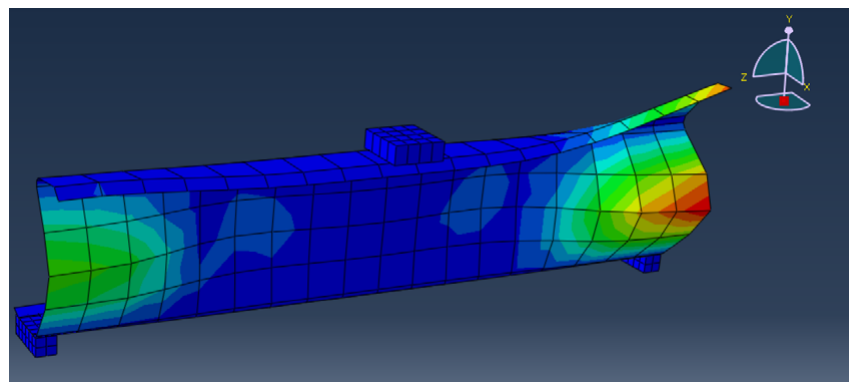

Figure 4: Web crippling of a Z-section stiffened flanges subjected to End-OneFlange loading.

\section{Proposed DSM for Web Crippling}

\section{Theory}

The key concept of DSM is to use the elastic buckling solution and the yield load of the entire section to predict the nominal strength of CFS members for each specific buckling mode. Eq. 2 is the main DSM equation for calculating the nominal axial strength of CFS columns in local buckling mode.

$$
\begin{aligned}
& \text { For } \lambda_{1} \leq 0.776, \mathrm{P}_{\mathrm{nl}}=\mathrm{P}_{\mathrm{ne}} \\
& \text { For } \lambda_{l}>0.776, \mathrm{P}_{\mathrm{nl}}=\left[1-0.15\left(\frac{\mathrm{P}_{\mathrm{crl}}}{\mathrm{P}_{\mathrm{ne}}}\right)^{0.4}\right]\left(\frac{\mathrm{P}_{\mathrm{crl}}}{\mathrm{P}_{\mathrm{ne}}}\right)^{0.4} \mathrm{P}_{\mathrm{ne}}
\end{aligned}
$$

Where $\mathrm{P}_{\text {crl }}$ is the critical elastic local buckling load and $\mathrm{P}_{\mathrm{ne}}$ is the nominal axial strength.

By extending the DSM to the calculation of web crippling strength, it is our purpose to use the same theory and similar function to predict the nominal web crippling strength. Equations 3 and 4 shows the proposed DSM equations for the nominal web crippling strength.

$$
\text { When } \lambda<=\alpha \text {, }
$$$$
P_{n}=A P_{y}
$$

When $\lambda>\alpha$

$$
P_{n}=B P_{y} \lambda^{-c}
$$

The $\alpha, \mathrm{A}, \mathrm{B}$ and $\mathrm{C}$ values changes with the respect to the loading condition and member cross-section shape. $\lambda=\sqrt{\frac{P_{y}}{P_{c r}}}, \mathrm{P}_{\mathrm{y}}$ is the yield load, $\mathrm{P}_{\text {cr }}$ is the critical elastic buckling load. The yield load $\mathrm{P}_{\mathrm{y}}$ can be calculated by Eq. 5 . $t$ is the thickness of the web and $\mathrm{N}$ is the bearing length.

$$
P_{y}=F_{y} N t
$$

\section{Experimental results in literature}

Tables 1-6 in Appendix list the geometries, test results and ABAQUS results for the existing tests collected from the literature on the web crippling of CFS $\mathrm{C}$ and $\mathrm{Z}$ sections subjected to one flange loading. The elastic buckling load, Pcr, was determined by the finite element analysis in ABAQUS.

\section{Proposed DSM equations}

The Direct Strength Method assumes that the ratio of the nominal strength/yield load $\left(\frac{\mathrm{P}_{t}}{\mathrm{P}_{\mathrm{y}}}\right)$ is controlled by the square root of the value of yield load divided by elastic buckling load, $\sqrt{\frac{\mathrm{P}_{\mathrm{y}}}{\mathrm{P}_{\mathrm{cr}}}}$. The proposed direct strength method equations were developed by accepting this assumption and using curve fitting methods. Based on availability of the experimental data in literature, a total of 6 web crippling cases (Table 1) were studied in this research.

Figures 5-10 illustrate the comparison between the experimental data and the proposed design equations.

\begin{tabular}{|c|c|c|c|}
\hline Section & Loading & Flanges & Supports \\
\hline C & IOF & Stiffened & Unfastened \\
\hline Z & EOF & Stiffened & Fastened \\
\hline C & EOF & Unstiffened & Unfastened \\
\hline Z & EOF & Stiffened & Unfastened \\
\hline C & EOF & Stiffened & Fastened \\
\hline C & EOF & Stiffened & Unfastened \\
\hline
\end{tabular}

Table 1: Web crippling cases studied. 
Citation: Dara M, Yu C (2015) Direct Strength Method for Web Crippling of Cold-formed Steel C- and Z- sections Subjected to One-flange Loading. J Steel Struct Constr 1: 105. doi:10.4172/jssc.1000105

Page 3 of 4

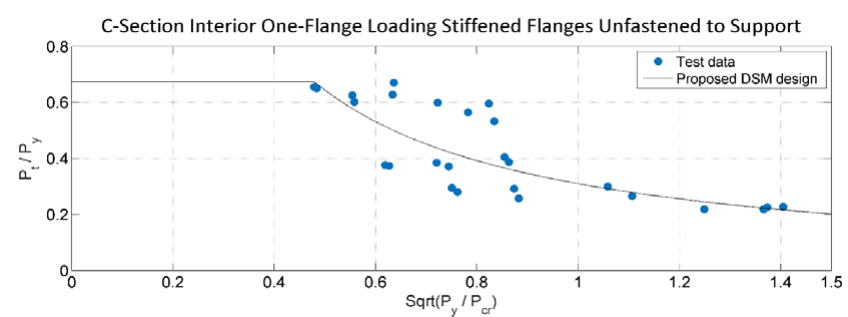

Figure 5: Comparison of DSM curves with test data for C-section IOF loading condition.

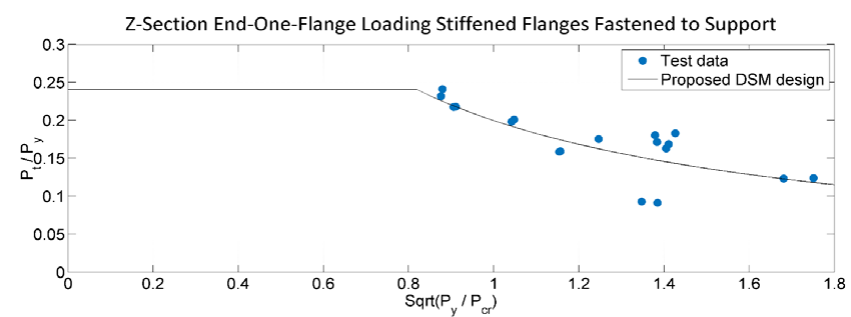

Figure 6: Comparison of DSM curves with the test data for Z-section EOF loading condition.

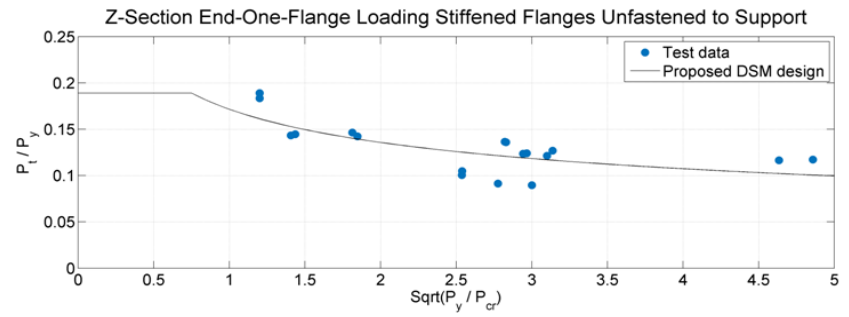

Figure 7: Comparison of DSM curves with test data for Z-section EOF loading condition.

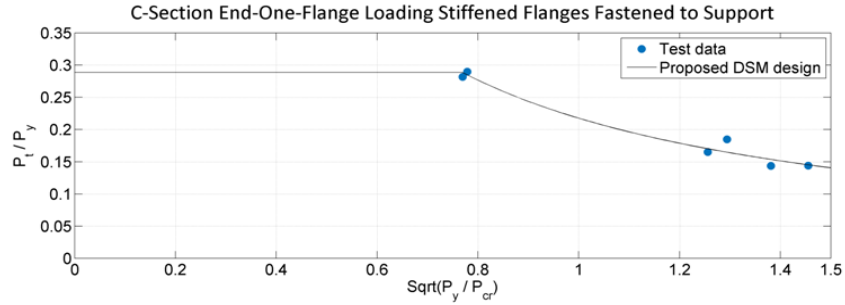

Figure 8: Comparison of C-section End-one-flange Loading DSM curves with the test data.

The proposed design equations used the same format (Equations 3 and 4), therefore a general equation with parameters can be used to express those equations. The final equations developed were generalized for calculating the web crippling strength and tabulated in Table 2. The $\mathrm{A}, \mathrm{B}$ and $\mathrm{C}$ values changes with the respect to the loading condition and member cross-section shape.

The research results indicate that the DSM concept works for the web crippling of CFS sections. In general, the DSM concept is suitable for the post-buckling strength of thin-walled steel members. Web crippling is one of the post buckling phenomena in the CFS structures. The challenge of implementing the proposed design method is that the elastic buckling solutions of the CFS sections shall be appropriately calculated. Additional research is needed to address the closed-formed solutions of elastic buckling loads for CFS members subjected to various web crippling failures.

\section{Resistance and safety factors}

Following AISI S100 (2012), the safety and resistance factors for the designed equations can be calculated. The calculated resistance and safety factors for each case is listed in Table 3.

The resistance factor, $\phi$, is calculated by the following equation

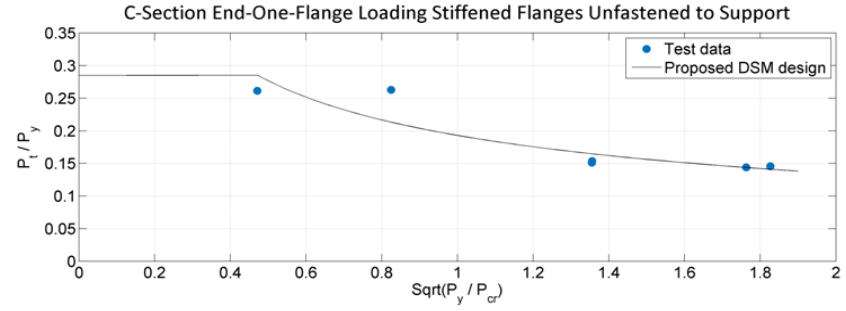

Figure 9: Comparison of DSM curves with the test data.

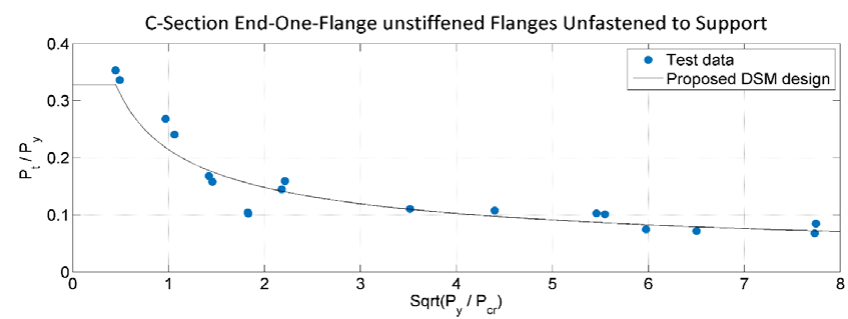

Figure 10: Comparison of DSM curves with test data for C-section EOF loading condition.

\begin{tabular}{|c|c|c|c|c|c|c|c|}
\hline Section & Loading & Flanges & Supports & $\alpha$ & A & B & C \\
\hline \multirow[t]{2}{*}{ C } & \multirow[t]{2}{*}{ IOF } & \multirow[t]{2}{*}{ Stiffened } & \multirow[t]{2}{*}{ Unfastened } & $<=0.48$ & 0.68 & - & - \\
\hline & & & & $>=0.48$ & - & 0.31 & -1.05 \\
\hline \multirow[t]{2}{*}{ Z } & \multirow[t]{2}{*}{ EOF } & \multirow[t]{2}{*}{ Stiffened } & \multirow[t]{2}{*}{ Fastened } & $<=0.82$ & 0.25 & - & - \\
\hline & & & & $>=0.82$ & - & 0.19 & -0.93 \\
\hline \multirow[t]{2}{*}{ C } & \multirow[t]{2}{*}{ EOF } & \multirow[t]{2}{*}{ Unstiffened } & \multirow[t]{2}{*}{ Unfastened } & $<=0.4$ & -0.36 & - & - \\
\hline & & & & $>=0.4$ & - & 0.21 & -0.53 \\
\hline \multirow[t]{2}{*}{ Z } & \multirow[t]{2}{*}{ EOF } & \multirow[t]{2}{*}{ Stiffened } & \multirow[t]{2}{*}{ Unfastened } & $<=0.75$ & 0.2 & - & - \\
\hline & & & & $>=0.75$ & - & 0.17 & -0.33 \\
\hline \multirow[t]{2}{*}{ C } & \multirow[t]{2}{*}{ EOF } & \multirow[t]{2}{*}{ Stiffened } & \multirow[t]{2}{*}{ Fastened } & $<=0.76$ & 0.29 & - & - \\
\hline & & & & $>=0.76$ & - & 0.21 & -1.08 \\
\hline \multirow[t]{2}{*}{ C } & \multirow[t]{2}{*}{ EOF } & \multirow[t]{2}{*}{ Stiffened } & \multirow[t]{2}{*}{ Unfastened } & $<=0.44$ & 0.28 & - & - \\
\hline & & & & $>=0.44$ & - & 0.19 & -0.52 \\
\hline
\end{tabular}

Table 2: Generalization of developed design equations.

\begin{tabular}{|c|c|c|c|c|c|}
\hline $\begin{array}{c}\text { Cross- } \\
\text { Section }\end{array}$ & $\begin{array}{c}\text { Loading } \\
\text { Condition }\end{array}$ & Flanges & $\begin{array}{c}\text { Support } \\
\text { conditions }\end{array}$ & $\begin{array}{c}\text { Resistance } \\
\text { Factor }\end{array}$ & $\begin{array}{c}\text { Safety } \\
\text { Factor }\end{array}$ \\
\hline C & EOF & Stiffened & Fastened & 0.89 & 1.78 \\
\hline C & EOF & Stiffened & Unfastened & 0.81 & 1.96 \\
\hline C & IOF & Stiffened & Unfastened & 0.72 & 2.21 \\
\hline Z & EOF & Stiffened & Fastened & 0.78 & 2.02 \\
\hline C & EOF & Unstiffened & Unfastened & 0.8 & 1.98 \\
\hline Z & EOF & Stiffened & Unfastened & 0.83 & 1.91 \\
\hline
\end{tabular}

Table 3: Safety and resistance factors for the proposed design method. 
Citation: Dara M, Yu C (2015) Direct Strength Method for Web Crippling of Cold-formed Steel C- and Z- sections Subjected to One-flange Loading. J Steel Struct Constr 1: 105. doi:10.4172/jssc.1000105

$\phi=C_{\varphi}\left(M_{m} F_{m} P_{m}\right) e^{-\beta_{o} \sqrt{V_{M}^{2}+V_{F}^{2}+V_{Q}^{2}+C_{P} V_{P}^{2}}}$

Where

$\mathrm{C}_{\phi}=$ Calibration coefficient

$=1.52$ for LRFD

$=1.42$ for $\mathrm{LSD}$

$\mathrm{M}_{\mathrm{m}}=$ Mean value of material factor [1]

$\mathrm{F}_{\mathrm{m}}=$ Mean value of the fabrication factor [1]

$P_{m}=\frac{\sum_{i=1}^{n} \frac{R_{t, i}}{R_{n, i}}}{n}$ Where,

$\mathrm{i}=$ index of tests

$=1$ to $\mathrm{n}$

$\mathrm{n}=$ total number of tests

$\mathrm{R}_{\mathrm{t}, \mathrm{i}}=$ tested strength [resistance] of test $\mathrm{i}$

$\mathrm{R}_{\mathrm{n}, \mathrm{i}}=$ calculated nominal strength [resistance] of test i per rational engineering analysis model

$\mathrm{e}=$ natural logarithmic base

$=2.718$

$\beta_{\mathrm{o}}=2.5$ for structural members for LRFD

$\mathrm{V}_{\mathrm{M}}=$ Coefficient of variation of material factor (taken from the Table F1 in AISI S100)

$\mathrm{V}_{\mathrm{F}}=$ Coefficient of variation of fabrication factor (taken from the Table F1 in AISI S100)

$\mathrm{C}_{\mathrm{P}}=$ correlation factor

$=\frac{\left(1+\frac{1}{n}\right) m}{m-2}$ for $n \geq 4$

$=5.7$ for $\mathrm{n}=3$

Where

$\mathrm{n}=$ number of tests

$\mathrm{m}=$ degrees of freedom $=\mathrm{n}-1$

$\mathrm{V}_{\mathrm{P}}=$ coefficient of variation of test results, but not less than 0.065

$\mathrm{V}_{\mathrm{Q}}=$ Coefficient of variation of load effect

$=0.21$ for LRFD

\section{Conclusions}

New design methods for calculating the nominal web crippling strength of the CFS C-sections and Z-sections subjected to EndOne-Flange loading and Interior One-Flange loading conditions were developed and verified by the experimental results. ASD Safety and LRFD resistance factors were calculated according to the AISI standards. ABAQUS is used as the main tool for calculating the critical elastic buckling load of the C-sections and Z-sections. The research proves that the concept of Direct Strength Method works for the web crippling strength of CFS members. Further analysis is needed to allow the Direct Strength Method to address other member types such as I sections, hat sections, etc., in web crippling.

\section{References}

1. AISI S100 (2012) North American Specification for the Design of Cold-Formed Steel Structural Members. 2012 Edition American Iron and Steel Institute, Washington, USA.

2. Winter G, Pian RHJ (1946) Crushing Strength of Thin Steel Webs. Engineering Experiment Station Cornell University Ithaca NY.

3. Zetlin L (1955) Elastic instability of flat plates subjected to partial edge loads Journal of the Structural Division.

4. Hetrakul N, Yu WW (1978) Structural Behaviour of Beam Webs subjected to Web Crippling and a combination of Web crippling and bending. Civil engineering study University of Missouri-Rolla, USA.

5. Yu WW (1981) Web Crippling and Combined Web Crippling and Bending of Steel Decks. Civil Engineering Study 81-2, University of Missouri-Rolla, Rolla, MO.

6. Santaputra C (1986) Web crippling of high strength of cold-formed steel beams University of Missouri-Rolla, USA.

7. Santaputra C, Parks MB, Yu WW (1989) Web-crippling strength of cold formed steel beams. J Struct Eng 115: 2511-2527.

8. Bhakta BH, LaBoube RA, Yu WW (1992) The Effect of Flange Restraint on Web Crippling Strength. Final Report, Civil Engineering Study 92-1, University of Missouri-Rolla, Rolla, MO.

9. Wing BA (1981) Web crippling and interaction of bending and web crippling of unreinforced multi-web cold-formed steel sections. University of Waterloo, Waterloo Canada.

10. Wing BA, Schuster RM (1982) Web crippling of decks subjected to two flange loading. Proceeding of the 6yh International Specialty Conference on ColdFormed Steel Structures, University of Missouri-Rolla, Rolla, MO.

11. Parabakaran K (1993) Web Crippling of Cold Formed Steel Sections Department of Civil Engineering, University of Waterloo,Canada.

12. Beshara B, Schuster RM (2000) Web Crippling Data and Calibrations of Cold Formed Steel Members. Research Report, RP00-2, American Iron and Steel Institute, Washington, USA

13. Young B, Hancock GJ (1998) Web Crippling Behavior of Cold-Formed Unlipped Channels. Proceedings of the 14th International specialty conference on ColdFormed Steel Structures, University of Missouri Rolla, USA.

14. Prabakaran K, Schuster PM (1998) Web crippling of cold-formed stee members. Proceedings of the 14th International Specialty Conference on Coldformed Steel Structures, S1. Louis, University of Missouri-Rolla, MO.

15. Beshara B (1999) Web crippling of cold-formed steel members. University of Waterloo, Waterloo, Canada

16. Schafer BW, Pekoz T (1998) Direct strength prediction of cold-formed stee members using numerical elastic buckling solutions. $14^{\text {th }}$ International Specialty Conference on Cold-Formed Steel Structures, St., Louis, MO.

17. Choy MY, Jia XF, Yuan X, Zhou J, Wang HS, et al. (2014) Direct Strength Method for Web Crippling of Cold-Formed Steel C- and Z- Sections Subjected to Two-Flange Loading. Proceedings of Annual Stability Conference, Structura Stability Research Council, Toronto, Canada.

18. Langan JE, Yu WW (1994) Structural Behaviour of Perforated web elements of Cold-Formed Steel Flexural Members Subjected to Web crippling and a combination of Web Crippling and Bending. Civil Engineering Study, Missouri University of Science and Technology, USA

Citation: Dara M, Yu C (2015) Direct Strength Method for Web Crippling of Cold-formed Steel C- and Z- sections Subjected to One-flange Loading. J Steel Struct Constr 1: 105. doi:10.4172/jssc. 1000105 